\title{
Measuring of Goodwill in Non-profit Organizations under the conditions of Globalization: The Case of Slovak Republic
}

\author{
Ivana Podhorska, ${ }^{1, *}$ \\ ${ }^{1}$ University of Zilina, Faculty of Operation and Economics of Transport and Communications, \\ Department of Economics, Univerzitna 1, 01026 Zilina, Slovakia
}

\begin{abstract}
.
Research background: Both the creation and quantification of goodwill are interdisciplinary issues affecting accounting, economics, law, marketing, sociology and human resources. In both economic theory and practice, goodwill is the difference between the market and the book value of an enterprise.

Purpose of the article: With the acceleration of globalization, the economic aspects of which are the logical consequence of the increasing interdependence of individual economies towards the end of the second half of the 20th century, the importance of building and managing goodwill as a competitive advantage through business activities and internationally is increasing. These facts should be more highlighted and stronger in the sector of non-profit organizations. Because of their mission, vision and character of their business. The main aim of the paper is to capture the value of goodwill in the sector of non-profit organizations in the Slovak Republic.

Methods: As a testing data will be used 72 non-profit organizations from Slovak Republic. In this sample will be quantified the value of their goodwill by residual income methods. Residual income assumes the value of goodwill as a difference between net income and the product of the cost of equity and the book value of equity.

Findings \& Value added: Paper findings will bring the view on the possibility of measuring goodwill in the sector of non-profit organizations under the conditions of globalizations with the emphasis on the application of residual income method in the case of Slovak Republic.
\end{abstract}

Keywords: goodwill; residual income; non-profit organization; globalization

JEL Classification: $G 3$; G32; F6

\footnotetext{
${ }^{*}$ Corresponding author: ivana.podhorska@,fpedas.uniza.sk
} 


\section{Introduction}

In general, goodwill has often defined as company reputation, image, good name, prestige, as well as the brand. It is reflected in the relationship between company and other market participants and company perception in the eyes of its customers. [1] Traditionally, we distinguish between two types of goodwill: namely, purchased goodwill and internally generated goodwill. Purchased goodwill is the difference between the value paid for an company as a going concern and the sum of its assets less the sum of its liabilities, each item of which has been separately identified and valued. Internally generated goodwill will be the main subject of interest in the paper, hereinafter referred as to "Goodwill". Company with goodwill has more satisfied and loyal customers and employees. Its suppliers are more willing to cooperate, as well as its investors are more tolerant and willing to finance business development. [1,2,3]

"Goodwill has created for years, but it can be destroyed almost every day." [4]

Goodwill, as an economic phenomenon has attracted the attention of economic experts since the nineteenth century. During years have been created various definitions and methods for its valuation and quantification. The issue of company goodwill is an interdisciplinary question; indicators of goodwill creation can be found in financial management, economics, law, marketing, sociologist, etc. However, knowledge and understanding of company goodwill indicators is still a managerial challenge. Their identification can lead to its effective creation and management, and ultimately to be a powerful tool in the competitive struggle.

\section{Literature review}

The earliest known commercial use of the English term ,goodwill“" was in 1571 although the idea which it conveys is probably much older. [5] Yet when Francis More read a paper on goodwill to the Chartered Accountants'Students'Society of Edinburgh in 1891, he felt the need to preface his remarks on valuation with an apology. [6] He regretted his inability to quote any authorities on the subject. He was unaware of any previous writings on goodwill valuation. [7,8] The earlier writings on goodwill had concentrated on legal aspects, particularly the protection of attendant property rigts. If anyone had considered the effect of different factors on price and how goodwill might be valued in the absence of the direct evidence of a market transaction, his poinion seems to have remained unpublished. Twentythree years after the appearance of More's paper, P. D. Leake first publsihed his view on the valuation of goodwill in a paper read to the Leicester Chartered Accountants' Students' Society. In the inverventing period, however, the subject seems to have aroused considerable interest, and several weiting included a discussion of it. Many factors contributed to this surge of interest. An increasing number of accountants were joining professional societics, many of which had been founded in the decade or so before 1891. There followed more organised opportunitites for the exchange of ideas within the profession and a greater concern for the attainment of acceptable standards of performance in professional duties. Consequently, writings on accounting subject became more numerous. $[9,10,11]$

In 1842, a judge Lord Eldon, the poinner in the legal direction described company goodwill: ,, Company goodwill, which is the subject of supply and demand, is the probability, that old customers come back to old places, nothing more... " [12]

In 1901 a judge Lord Macnaughton, IRS vs Muller and Co's Margine Ltd., described company goodwill: ,, What is goodwill? It is something very simple for description, and very difficult for defiction, on the other hand. Goodwill is the benefits from company good reputation and business relationships. " [13]

The second one, economic direction, had different view of company goodwill. In 1922, W. A. Paton American accountancy scholar, known as founder of the American Accounting 
Association in 1916, and founder and first editor of its flagship journal „The Accounting Review“, defined company goodwill in ",Ronald Press “: ,, goodwil is an intangible assets and its value repesents the difference between the total value of company and the sume of its tangible assets. Goodwill is the company ability to create abnormal earnings. " [14]

Yang (1927) published study ,, Goodwill and Other Intangible Assets “, where he defined goodwill: , company goodwill is the sum of the present value of the future expected income of the incumbent company which the newly established company would not be able to achieve. " [15]

Catlett et al. in 1968 published their research as "Accounting Research Study No. 10“ where described goodwill as "abnormal income capacity." [16]

Tearney published study „Accounting for Goodwill: A Realistic Approach “ in 1973, where he stated: ,,goodwill is the item, which includes many other intangible items. " [17]

Feltham and Ohlson in their study ,Valuation and Clean Surplus Accounting for Operating and Financial Activities " published in 1995 supposed: "the value of the company is formed by the sum of the book value of the company equity and the present value of the expected future residual income... (...) goodwill is the present value of future residual income. " [18]

The following quote from the study of Smith and Stanton in 1999 "Goodwill Hunting. An Examination of the Nature and Accounting Treatment of Goodwill" states: "it is not acceptable to include goodwill in assets in the financial statements because of it partially reflects the judgment derived from these financial statements. " [19]

Maly (2002) noted: ,goodwill is good reputation of company in its business partners, financial institutions, public, customers... in domestic markets and also in abroad. " [20] Bloom in „Double Accounting for Goodwill: A Problem Redefined” in 2008 stated: ,there is a significant controversy between what goodwill is and its resources because it is an interdisciplinary issue. " [21]

Other authors who tried to define goodwill include Suchanek, who states in his study in 2009: "goodwill clearly reflects company position on the market, the quality of its production, tradition, reputation in the eyes of its main customers and so on. It is evident that such it really requires a long time and a considerable effort in terms of promotion." [22,23]

Interesting also is the opinion from online paper "Goodwill of the Company", which was published in 2015 in the Czech Republic: "goodwill is a good reputation of company, the loyalty of its customers, quality of employees, advantage of strategic location or outlets, organizational structure... It thus represents the amount which arises from the difference between the accounting valuation of the company and the market valuation of the company. " [24]

\section{Methodology}

\subsection{Goodwill valuation - residual income method}

Residual income represents income, which enterprise created over the level of the income required by its owners. Determination of required income for owners is necessary. According to the residual income theory by Feltham and Ohlson (1995), the required income for owners is equal to the cost of equity. Disadvantages are special barriers in the process of their quantification, especially under the condition of the inefficient capital market, as well as in Slovak Republic. Quantification of residual income has the following form: 


$$
R I=N I-\text { equity charge }
$$

where

RI residual income

NI net income

The determination of equity charge represents the key calculation of the residual income. Due to the fact, equity charge is the product of the book value of equity and its cost. This fact depicted in the following equation:

$$
\text { equity charge }=r_{E} * B V_{E_{t-1}}
$$

where

$r_{E} \quad$ cost of equity

$B V_{E_{t-1}} \quad$ book value of equity

The cost of equity is calculated by CAPM with country risk premium (CRP). According to Damodaran.

$$
r_{E}=r_{f U S A}+\beta * E R P_{U S A}+C R P
$$

where

$r_{f U S A}$ risk-free rate; yield of bonds that calculate the risk premium of the market, i.e. the yield of US 10-year government bonds according to Damodaran website

ERP equity risk premium $\left(R_{m}-r_{f}\right) ; R_{m}$ represents S\&P500 according to Damodaran website

$\beta \quad$ beta for emergning markets according to Damodaran website

CRP risk premium for other markets according to Damodaran website

\subsection{Data and sample}

As a testing data will be used 72 non-profit organizations from Slovak Republic. Data contain their financial statements from 2018. In this sample will be quantified the value of their goodwill by residual income methods. These data were obtained from the Amadeus database system - a comprehensive European database on public and private companies.

\section{Results}

Table no. 1 demonstrated partial calculation of residual income in database of 72 non-profit organizations. It shows input variables for residual income calculation in 18 companies. 


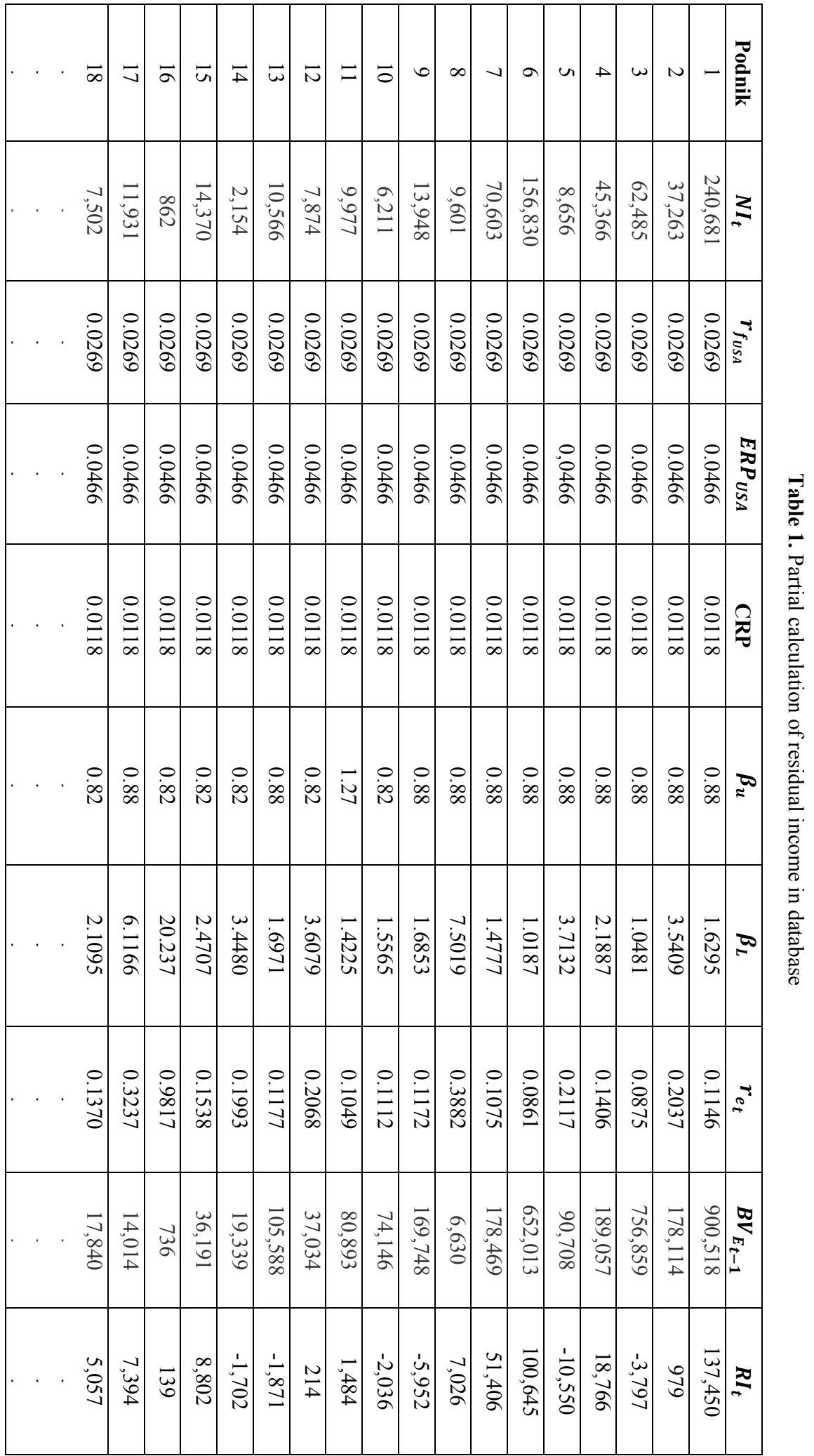


Table 2. Matrix of changes

\begin{tabular}{|l|c|c|c|}
\hline \multirow{3}{*}{ Real data } & \multicolumn{3}{|c|}{ Model data } \\
\hline & & goodwill & badwill \\
\cline { 2 - 4 } & goodwill & True positives & False negatives \\
\cline { 2 - 4 } & badwill & False positives & True negatives \\
\hline
\end{tabular}

Table no. 2 shows theoretical aspects of matrix of changes. The matrix of changes classifies companies into two categories: (i) companies with goodwill, (ii) companies without goodwill (badwill). Results of residual income method in the 72 non-profit organizations represented real data, results of economic value added in the 72 non-profit organizations represented model data. Economic value added was chosen as another method which can be used for calculation of the value of company and it can be used as a comparison method to residual income method. There are four situations: (i) true positives - both of methods achieved the same results; (ii) false positives - methods achieved different results; (iii) false negatives and (iv) true negatives - both of methods achieved the same results.

Table 3. Matrix of changes - comparison residual income method and economic value added

\begin{tabular}{|c|c|c|c|c|}
\hline & \multicolumn{3}{|c|}{ Model data-economic value added } & \multirow{2}{*}{ Total } \\
\hline \multirow{2}{*}{$\begin{array}{c}\text { Real } \\
\text { data }- \\
\text { residual } \\
\text { income }\end{array}$} & goodwill & goodwill & badwill & 49 \\
\cline { 2 - 5 } & badwill & 42 & 7 & 23 \\
\hline & & 51 & 14 & 72 \\
\hline
\end{tabular}

Table 4. Residual income method accuracy

\begin{tabular}{|l|l|}
\hline & Residual income method \\
\hline Overall model accuracy & $77.78 \%$ \\
\hline Model sensitivity & $85.71 \%$ \\
\hline Model specificity & $56 \%$ \\
\hline Type I error & $14.14 \%$ \\
\hline Type II error & $12.5 \%$ \\
\hline
\end{tabular}

As a testing data were used 72 non-profit organizations from Slovak Republic. Data contained their financial statements from 2018. In this sample were quantified the value of their goodwill by residual income methods. These data were obtained from the Amadeus database system - a comprehensive European database on public and private companies. Research results demonstrated that 52 companies from database created goodwill (calculated by residual income method) and 20 companies not (tables no. 3 and 4, fig. no. 1). These findings were compared with results of economic value added which calculated the value of company for its owners. Subsequently, matrix of change demonstrated this comparison. 42 companies achieved the same results by the both of methods and 14 companies not. The results were different in the 16 cases. Residual income method identified 7 companies as a company with goodwill and economic value added these companies identified as a company without goodwill. Subsequently, residual income method identified 9 companies as a company without goodwill and economic value added these companies identified as a 
company with goodwill. Overall model accuracy represents $77.78 \%$ with model sensitivity $85.71 \%$ and its specificity represents $56 \%$.

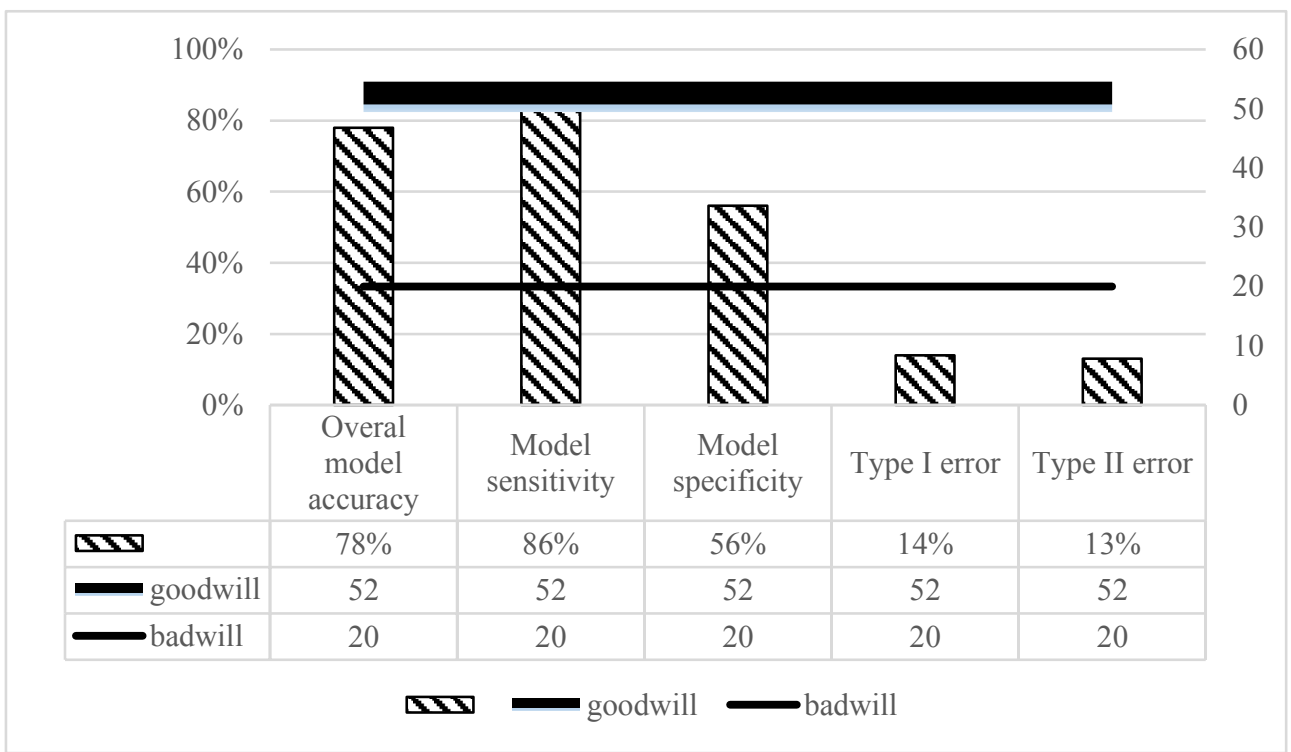

Fig. 1. Residual income method accuracy

\section{Discussion and conclusion}

Company goodwill valuation and identification belong into the interdisciplinary challenges. Potential sources of goodwill creation can be found in various sectors, e.g. economics, sociology, law, marketing, etc. Tsai, et. al. (2012; 2016) considered investing, advertising, research and development as significant sources of enterprise goodwill. However, this research brings various limitations. It is necessary to highlight several various limitations for this study and studies about goodwill, its valuation and identification, as a whole.

The issue of goodwill is very discussed topic in scientific communite what is demonstrated by number of goodwill publications per year. While at the beginning of the last century (1912) the number of goodwill publications fluctuated at the level of 0-2 publications per year, at the beginning of the 21 st century their number increased significantly. In 2000 2006 it was up to 20 goodwill publications per year. Between 2007 and 2010, were published 50 goodwill publications per year. The highest number of goodwill publications in scientific databases has so far appeared in 2011, almost 100 publications. This topis is also interdisciplinary it extends not only to typical economic areas such as corporate finance (which has the largest share of goodwill publications, more than 200, which represents 29.52 $\%$ ), economics ( 86 publications, $10.94 \%$ ), but also law (60 publications, $7.63 \%$ ) social and political sciences (26, $3.3 \%$ and 20 publications $2.55 \%$ ), during 1912-2019. Among to the most cited authors dealing with the goodwill belong e.g. Shenkar (1997), Beatty (2006), but also publications by Tearney (1973) or Seetharaman (2006).

The aim of the paper was to capture the value of goodwill in the sector of non-profit organizations in the Slovak Republic. As a testing data were used 72 non-profit organizations from Slovak Republic. Data contained their financial statements from 2018. In this sample were quantified the value of their goodwill by residual income methods. These data were 
obtained from the Amadeus database system - a comprehensive European database on public and private companies. Research results demonstrated that 52 companies from database created goodwill (calculated by residual income method) and 20 companies not. These findings were compared with results of economic value added which calculated the value of company for its owners. Subsequently, matrix of change demonstrated this comparison. 42 companies achieved the same results by the both of methods and 14 companies not. The results were different in the 16 cases. Residual income method identified 7 companies as a company with goodwill and economic value added these companies identified as a company without goodwill. Subsequently, residual income method identified 9 companies as a company without goodwill and economic value added these companies identified as a company with goodwill. Overall model accuracy represents $77.78 \%$ with model sensitivity $85.71 \%$ and its specificity represents $56 \%$. Paper findings demonstrated that residual income method achieved relevant results in the non-profit sector. For this reason, can be assume that this method should be apply in non-profit sector for company goodwill valuation.

Grant No. 1/0544/19 Formation of the methodological platform to measure and assess the effectiveness and financial status of non-profit organizations in the Slovak Republic.

\section{References}

1. Reilly, R. F. (2015). Goodwill valuation approaches, methods, and procedures“. American Bankruptcy Insitute Journal, 34, 10-24.

2. Heathcote, J., Perri, F. (2018). Wealth and volatility. Review of Economic Studies, 85(4), 2173-2213.

3. Wilson, J. M., Grammich, C. A. (2020). Brand protection across the enterprise: Toward a total-business solution. Business Horizons, 63(3), 363-376.

4. Nelson, H. R. (1953). The momentum theory of goodwill. The Accounting Review, 28, 491-499.

5. Bartosovoa, V., Kral, P. (2016). Methodological framework of financial analysis results objectification in the Slovak Republic. Proceedings of 3rd International Conference on Business and Economics (pp. 189-197). Malaysia.

6. Rebetak, F., Bartosova, V. (2020). Non-profit organizations in the conditions of Slovakia. 19th International Scientific Conference Globalization And Its SocioEconomic Consequences 2019 - Sustainability In The Global-Knowledge Economy (Article Number 05020). Rajecke Teplice: SHS Web of Conference.

7. Gao, P., Jiang, X., Zhang, G. (2019). Firm value and market liquidity around the adoption of common accounting standards. Journal of Accounting \& Economics, 68(1), 101220.

8. Siekelova, A., Kovacova, M., Adamko, P. et al. (2019). Profit management as an instrument for SMEs developing: The case for Slovakia. Marketing and Management of Innovations, 3, 285-296.

9. Connelly, B. L., Shi, W., Hoskisson, R. E. et al. (2019). Shareholder influence on joint venture exploration. Journal of Management, 45(8), 3178-3203.

10. Ajaz Khan, K., Cera, G., Netek, V. (2019). Perception of the selected business environment aspects by service firms. Journal of Tourism and Services, 10(19), 111127.

11. Connolly-Barket, M., Kliestik, T., Suler, P., Zvarikova, K. (2020). Real-time decisionmaking in the information technology-driven economy: Planning, manageing and 
operating smart sustainable cities. Geopolitics, History, and International Relations, 12(1), 73-79.

12. Siekelova, A. (2015). The role of the receivables management in conditions of globalization. In : Kliestik, T. (eds.), Proceeding of the 15the International Scientific Conference on Globalization and its Socio-Economic Consequences (pp. 686-690). Rajecke Teplice : PRoceedings Paper.

13. Guo, J.-T., Hung, F.-S. (2020). Tax evasion and financial development under asymmetric information in credit markets. Journal of Development Economics, 145, Article Number 102463.

14. Paton, W. A. (1922). Accounting Theory. New York : Roland Press.

15. Yang, J. M. (1927). Goodwill and other intangible assets. New York : Ronald Press.

16. Catlett, G. R., Olson, N. O. (1968). Accounting research study no. 10. New York: Aicpa,

17. Tearney, M. G. (1973). Accounting for goodwill: A realistic approach. Journal of Accountancy, 136(1), 41-45.

18. Feltham, G., Ohlson, J. A. (1995). Valuation and clean surplus accounting for operating and financial activities. Contemporary Accounting Research, 11(2), 689-731.

19. Ashander, L, Kliestikova, J., Durana, P., Vrbka, J. (2019). The decision-making logic of big data algorithmic analytics. Contemporary Readings in Law and Social Justice, 11(1), 57-62.

20. Maly, J. (2002). Obchod nehmotnými statky. Praha: C. H. BECK.

21. Bloom, M. (2008). Double accounting for goodwill: A problem redefined. New York: Taylor \& Francis group.

22. Eliason, P. J., Heebsh, B., Mcdevitt, R. C., Roberts, J.W. (2020). How acquistions affect firm behavior and performance: Evidence from the dialysis industry. Quarterly Journal of Economics, 135(1), 221-267.

23. Ghatak, M., Maniquet, F. (2019). Universal basic income: Some theoretical aspects. Annual Review of Economics, 11, 895-928.

24. Groves, P. (2011). A dictionary of intellectual property law. Cheltenham: Edward Elgar Publishing Limited. 